\author{
АНДРЕЙ Л. ШЕМЯКИН \\ Институт славяноведения \\ Российской академии наук \\ anshemjakin@rambler.ru
}

\title{
НИКОЛА ПАШИЧ И РОССИЯ. ИЗ ИСТОРИИ ВЗАИМООТНОШЕНИЙ
}

\begin{abstract}
Аннотация: Статья содержит в себе целый спектр мнений о природе русофильства Николы Пашича. В то время, как одни интерпретаторы считают, что оно опиралось на чисто прагматические соображения, другие на первый план выдвигают русско-сербское кровное и религиозное родство, как его решающий фактор. Далее автор высказывает собственную точку зрения относительно корней «безусловного» прорусского настроя Н. Пашича. В основе его лежало цивилизационное определение - подобно русским славянофилам, Пашич и основанная им Радикальная партия выступали за сохранение сербской самобытности в условиях резко усилившегося после 1878 г. «наступления» Европы на Балканы. В заключении кратко представлены практические отношения вождя сербских радикалов с российскими властью и обществом.
\end{abstract}

Ключевые слова: Никола Пашич, Россия, идеология, славянофилы, западники, модернизация Сербии, Милан Обренович, Александр III, Николай II.

\author{
1. Русофильство Н. Пашича: \\ оценки интерпретаторов и подлинная природа \\ «В непрестанной борьбе Запада с Востоком \\ сербский народ всегда был на стороне Востока» \\ (Н. Пашич)
}

И 3 всех сторон противоречивой личности Николы Пашича (1844-1926), пожалуй, только одна ни у кого не вызывает сомнений и не порождает споров - это отношение к России. Тезис о безусловной прорусской ориентации бессменного вождя Народной радикальной партии давно уже стал общим местом в мировой историографии. Вот только с чем - с идеологией или политической конъюнктурой - связывают такую его позицию исследователи? Иными словами, какова была природа стойкого русофильства знаменитого Байи? 
Большинство ученых и публицистов считают решительный поворот Н. Пашича к России чисто политическим шагом, в основе которого лежал голый расчет, - иначе как объяснить тот факт, что близкий на рубеже 1860-1870- х годов друг и последователь русских эмигрантов-социалистов в Цюрихе ${ }^{1}$ спустя каких-то десятьдвенадцать лет превратился в стойкого приверженца официального Петербурга? Механизм этого поворота предельно четко обрисовал классик сербской историографии Слободан Йованович. «Воспитанные в школе русских социалистов, - писал он, - радикалы без симпатий относились к царской России. В своих внешнеполитических воззрениях они придерживались программы Светозара Марковича, согласно которой освобождение Балканского полуострова должно было произойти путем объединения усилий самих балканских народов без покровительства какой бы то ни было великой державы». Между тем «в эмиграции (т.е. в середине 1880-х годов. - А.Ш.) Пашич пришел к выводу, что даже если Россия не нужна балканским народам в деле освобождения Балкан, она необходима радикалам в деле свержения короля Милана Обреновича (их злейшего внутреннего врага. - A.Ш.)» ${ }^{2}$. Тогда же беглец «вошел в контакт с русскими, и эти связи уже никогда не прерывались» ${ }^{3}$. Впрочем, делает важное замечание автор, «в то время он еще не выглядел законченным русофилом» ${ }^{4}$. Данный вывод почти дословно продублировал Никола Б. Попович, особо выделив при этом прагматизм Н. Пашича ${ }^{5}$

Мнение Сл. Йовановича разделил публицист Душан Шиячки: «Во время эмиграции Пашич установил тесные связи с российскими официальными кругами» ${ }^{6}$. А историк Джордже Раденкович даже несколько снизил временной порог. Уже в 1881 г., подчеркнул он, «Пашич сделал окончательный выбор в пользу царской России, которая отныне будет его главной политической и дипломатической опорой» ${ }^{7}$. Столь же категоричен и бывший посланник Сербии в Петербурге Димитрие Попович: «Еще в начале своей политической карьеры Пашич стал преданным сторонником России» ${ }^{8}$. А Милан Ст. Протич-Старший (сын соратника Пашича Стояна Протича) подчеркивает, опровергая Сл. Йовановича: «Совершенно ясно, что во время эмиграции Пашич уже был человеком России, принадлежа ей даже больше, чем Сербии Обреновичей» ${ }^{9}$.

Наряду с внутриполитической, у русофильства радикального лидера имелась и сильная внешняя мотивация. Она была связана как с необходимостью окончательного решения сербского национального вопроса, так и со сложным

\footnotetext{
${ }^{1}$ Подробнее об этом см.: Šemjakin 2008: 50-94.

2 Jovanović 1991: 144-145.

${ }^{3}$ Ibid: 517.

${ }^{4}$ Ibid: 463.

${ }^{5}$ Popović N. 1997: 234.

${ }^{6}$ Šijački 1925: 30.

${ }^{7}$ Radenković 1997: 129.

${ }^{8}$ Popović D. 1937: 137.

${ }^{9}$ Protić 1971: 106.
} 
геополитическим положением самой Сербии: владения Австро-Венгрии непримиримой противницы не то что решения, но даже постановки этого вопроса, оккупировавшей к тому же Боснию и Герцеговину - полукольцом охватили территорию страны, что поставило под сомнение ее реальную независимость. Учитывая постоянно тлевший русско-австрийский антагонизм на Балканах, он и сделал ставку на Петербург: «Самая большая опасность для сербского элемента исходит от Австро-Венгрии, и единственно Россия может нас спасти от нее, ибо в таком случае она будет защищать и свои интересы» ${ }^{10}$.

На данное обстоятельство еще в 1926 г. обратил внимание известный сербский дипломат Мирослав Спалайкович: «Пашич рано понял то, чего не хотел или не мог понять Милан Обренович (последовательный австрофил. - А.Ш.) <..>. Он четко осознал, что в опоре на Австро-Венгрию у Сербии нет спасения. Решение своей национальной задачи она могла искать только в содружестве с другими балканскими народами и Россией. Когда эта истина стала очевидной, все остальное пошло само собой, как бы по инерции» ${ }^{11}$.Год спустя политик и публицист Милош Трифунович также отдал Н. Пашичу должное за его внешнеполитический выбор. «Повернуть Сербию от ее мощной соседки - Австро-Венгрии лицом к России, - писал он, - есть великий исторический шаг. Именно Пашич стал персонификацией этого судьбоносного поворота» ${ }^{12}$. Схожую мысль высказал и русский историк-эмигрант Алексей Елачич, особо подчеркнув социальную обусловленность сделанного выбора: «Князь Милан (Обренович. - А.Ш.) так активно искал австрийского покровительства, что вверг Сербию в состояние полной экономической и политической зависимости от Вены. Столь явный крен, однако, не принес сербам пользы. Поэтому народ, в огромном своем большинстве, требовал установления самых близких отношений с Россией, в чем его активно поддержали радикалы. Ну, а среди них наиболее последовательным русофилом был лидер партии Никола Пашич» ${ }^{13}$.

Что касается послевоенных исследователей, то и они нередко выделяют в его выраженной пророссийской ориентации лишь внешний компонент. «"Тяжело с Россией, но еще хуже без нее“, - гласил известный принцип. Вплоть до большевистской революции его непоколебимо придерживался Никола Пашич», писал Милан Гаврилович (в свое время секретарь сербского премьера) $)^{14}$. «Если рассматривать русофильство Пашича под микроскопом, - читаем у Васы Казимировича, - то становится очевидным следующее - в первую очередь оно являлось результатом политики, направленной на обеспечение Белграду помощи и поддержки со стороны России как великой державы. Особенно в его отношениях с Веной, а затем и с Софией» ${ }^{15}$. По мнению российского академика Сергея Дмитриевича Сказкина, Пашич и его соратники «всячески поддерживали

\footnotetext{
${ }^{10}$ Perović 1997: 696.

${ }^{11}$ Spalajković 1926: 35.

12 Trifunović 1927: 201.

${ }^{13}$ Elačić 1940: 88.

${ }^{14}$ Gavrilović 2015: 90.

${ }^{15}$ Kazimirović 1990: 63.
} 
русофильские настроения в расчете на помощь России против Австрии. Они не боялись вмешательства русского абсолютизма в их дела. Россия слишком далека, чтобы производить в Сербии эксперименты, но угроза Австрии русской дружбой была небесполезной» ${ }^{16}$. Синтезирует суждения этой группы авторов вывод Милана Ст. Протича-Младшего: «Пророссийская позиция Радикальной партии прошла в своей эволюции несколько этапов. Сначала источником близости были влияние русских социалистических мыслителей и романтическое чувство принадлежности к великому славянскому и православному миру. Но по мере того, как шло время, реальность гасила воодушевление. Радикалы обрели в России опору для реализации своей национальной программы» ${ }^{17}$.

Итак, на поиски союза с Петербургом Николу Пашича толкала задача сохранения независимости Сербии. Как, впрочем, и стремление обеспечить себе крепкий тыл в условиях острейшего внутреннего противостояния. Кроме того, союзничество России представлялось ему важнейшим фактором будущего «освобождения и объединения». Мотивировка, как видим, предельно логичная, а главное - вполне рациональная.

Но откуда тогда налет экзальтации, присущий русофильству Пашича «безусловному», как выразился Сл. Йованович ${ }^{18}$, или «эмоциональному», по оценке Димитрие Джорджевича? ${ }^{19}$ Отчего, по замечанию Душана Николаевича, «ни протоиерей Матия Ненадович, ни Йован Ристич, с которыми Пашича объединяла известная схожесть характеров, не были русофилами до той меры, как он» ${ }^{20}$ ? Что, наконец, дало основание профессору Джордже Станковичу заключить: «Поиск опоры в России имел для Пашича более глубокий смысл, чем тот, каковым руководствовались его предшественники» ${ }^{21}$ ? Хотя, наверное (добавим от себя), они были не меньшими патриотами и прагматиками.

Дж. Раденкович видит ответы на все эти вопросы в том же сугубом расчете. Пашич, по его словам, хотел «быть в Сербии человеком, которого мощная Россия больше всех ценит и уважает, кому всегда готова прийти на помощь <...>. Он как бы предлагал себя, желая оказаться балканской надеждой русской политики» ${ }^{22}$. С внутренним определением, а не только с такого рода практицизмом, связывает означенную черту его русофильства Н.Б. Попович: «Освобождение и объединение сербских земель в единое государство <..> были заветной мечтой Пашича. Но добиваться их осуществления предстояло в рамках определенного международного порядка, который жестко поставил перед сербами дилемму - с кем вы, с Россией или Австро-Венгрией? Для такого глубоко православного человека, как Никола Пашич, Россия уже по самой своей сути была призвана стать союзницей православных сербов. По той же причине он видел в ней ,законную“ противницу Австро-Венгрии.

\footnotetext{
${ }^{16}$ Skazkin 1974: 257.

${ }_{17}$ Protić 1900: 110-111.

18 Jovanović 1991: 166.

19 Đorđević 1997: 369.

${ }^{20}$ Nikolajević 1927: 45.

${ }^{21}$ Stanković 1985: 80.

22 Radenković 1997: 227.
} 
Ну, а если глобальные национальные интересы совпадают, то что другое остается, кроме как вести (и проводить постоянно) политику тесной дружбы с Россией $<\ldots>$. Поэтому считаться русофилом (с точки зрения внутреннего состояния духа) и придерживаться пророссийской линии (в качестве государственного деятеля) было для Пашича совершенно естественным и „Богом данным“ выбором. Не являться же таковым и не делать этого - суть грех и насилие над естеством; политика, направленная в ущерб народу» ${ }^{23}$. Еще в 1925 г. данную идею, в виде чеканной формулы, выразил историк и «верный» человек вождя сербских радикалов в России Радослав Йованович: «господин Пашич любит Россию глубоко и органично, как чтото фундаментальное, близкое и свое» ${ }^{24}$.

Мысль о принадлежности сербов и русских к одному общему миру (славянскому и православному), как о главном источнике его русофильского определения была весьма популярна и в межвоенной литературе. «Убеждение Пашича, его „верую“, - писал, к примеру, Момчило Ивкович, - состояло в том, что все славяне, а особенно мы - сербы, должны всегда быть вместе с Россией и русским народом» ${ }^{25}$. А потому, резюмировал Д. Николаевич, «веря в Россию, Пашич верил в себя» ${ }^{26}$.

Весьма экстравагантную, если не сказать скандальную, точку зрения на истоки «безусловного» русофильства Н. Пашича высказал в свое время известный публицист Светолик Гребенац. В одной из частных бесед он заявил: «Пашич вернулся в Сербию после учебы в Швейцарии, уже будучи агентом русской тайной полиции, которая и направила его в лагерь сербских социалистов и нигилистов, чтобы иметь представления об их связях с русскими революционерами» ${ }^{27}$. Ту же версию С. Гребенац выдвинул и печатно, объявив данное «качество» Пашича главной причиной того, что «характер его связей с Азиатским департаментом петербургского МИД намного превосходил нормальные дружеские отношения, которые существуют между двумя союзными государствами», и что он приглашался «на обеды в интимном кругу царской семьи» (о чем ниже). «Подобной чести удостаивались лишь самые преданные друзья императорской фамилии» ${ }^{28}$. Приведя эту версию как пример явно конъюнктурного мышления, оставим ее на совести автора...

Итак, в объяснении русофильства Николы Пашича, кроме чистой прагматики, появился новый мотив - мотив культурно-религиозной (социокультурной) общности Сербии и России и их «призванности» противостоять совместному неприятелю. Но ограничиваться одной лишь констатацией этого (несомненно, верного) посыла не стоит: следует детально рассмотреть его. В центре же нашего анализа должна находиться проблема взаимоотношений Запада и Востока, как двух цивилизационных полюсов - надобно выяснить, какое место между ними отводил Н. Пашич своей стране.

\footnotetext{
${ }^{23}$ Popović N. 1997: 237.

${ }^{24}$ Цит. по: Perović 1993: 149.

${ }^{25}$ Ivković 1926: 26.

${ }^{26}$ Nikolajević 1927: 45.

${ }^{27}$ Rukopisno odeljenje Matice srpske, Zaostavština Milana Jovanovića-Stojimirovića, M 13413.

${ }^{28}$ Grebenac 1926: 426.
} 
После Берлинского конгресса 1878 г., существенно изменившего геополитическую расстановку сил на Балканах, ведущие западно (средне) европейские страны начали свое мощное проникновение в регион. Сербия, оказавшись в сфере влияния Австро-Венгрии, сразу же ощутила на себе ее воздействие - политическое, экономическое, культурное. Оно ускорило процесс идейного размежевания в среде немногочисленной сербской элиты и способствовало консолидации ее основных фракций.

В 1880 г. откровенный прежде русофил Милан Обренович открыто перешел на австрофильские рельсы, связав судьбу страны и династии с Веной. Столь резкий поворот сербского монарха означал не только кардинальную смену его внешнеполитических ориентиров. Став первым в истории независимой Сербии событием знаковым, он отразил качественный сдвиг в сознании элиты в условиях, когда само обретение государственного суверенитета поставило перед Княжеством новую проблему - проблему выбора перспективного пути социокультурного развития. Последствия не заставили себя ждать - осенью того же года «старых» либералов-националистов Йована Ристича сменила у руля правления группа будущих напредняков, вобравшая в себя цвет европейски образованной, а главное ориентированной сербской интеллигенции. Предводимые Миланом Пирочанцем, новые министры - «либералы второго поколения» - видели свою цель в скорейшей модернизации (европеизации) патриархальной Сербии. Они поддержали проавстрийский «новый курс» Милана Обреновича, полагая, что именно Вена должна стать для Белграда окном в Старый Свет.

Прямо противоположную позицию заняла Народная радикальная партия, являвшаяся политической версией сербского социализма и идейно произраставшая из него. Отрицая универсальный характер пути Европы и ее образцов, радикалы в качестве главной задачи провозгласили защиту сербской самобытности, каковую отождествляли с только что обретенной национальной независимостью. «Мы совсем не бережем того, что серба делает сербом, - утверждал Никола Пашич, - но следуя моде, стремимся к тому, чем так кичатся иностранцы» ${ }^{29}$.

Острая борьба, развернувшася между представителями обеих тенденций, никого не оставила в стороне: в ее водоворот оказались втянутыми как монарх, так и широкие народные массы. «Либеральная идея и традиция» - эта сквозная дихотомия определяла все зигзаги сербской истории двух последних десятилетий XX в.

Внутреннее противостояние в Сербии весьма напоминало идейный конфликт западников и славянофилов в России ${ }^{30}$, что свидетельствует о типологической

\footnotetext{
${ }^{29}$ Arhiv Srpske akademije nauka i umetnosti (=ASANU), Pašićeve hartije, 14615-1-27.

${ }^{30}$ Славенко Терзич считает, что в Сербии «зазор» между либеральной и традиционалистской элитами (по обретении страной независимости) не был столь глубок, как в отношениях западников и славянофилов в России (см.: Terzić 1997: 140). Тезис, на наш взгляд, весьма сомнительный. Ведь в письме И. А. Зиновьеву (1887) Н. Пашич четко провел границу между двумя лагерями, на которые разделилась Сербия и которые вошли между собой в настоящий клинч. «Либеральная и Прогрессивная
} 
закономерности борьбы между либералами (европеистами) и традиционалистами (самобытниками) в аграрном обществе на этапе его перехода из традиционного состояния в современное (modern), или из закрытого в открытое, как сказал бы Карл Поппер ${ }^{31}$. Но упоминание о России в сербском контексте оправдано еще и потому, что идеи двух русских «почвеннических» школ - народничества и славянофильства, пропагандировавших (каждая по-своему) особый, т.е. не западный, путь ее развития, оказали самое непосредственное влияние на здешних приверженцев традиции. В данной связи совершщенно права Любинка Трговчевич: «Насколько значительным для сербского общества XIX в. было столкновение старого и нового, патриархального и современного, настолько же ключевой в идейном плане оказывалась дихотомия Европа или Россия». И далее: «Обращение к России в моменты сомнения в истинности западных идеалов - одно из типичных явлений, имевших место в среде сербской интеллигенции той поры» ${ }^{32}$.

Пример радикальных идеологов наглядно подтверждает такой вывод. Сербский путь к прогрессу, согласно их народнической доктрине, лежал вне либеральнокапиталистической модели, активно насаждавшейся напредняками. Европейский капитализм, с присущими ему культом индивидуалистического начала и тенденцией к расслоению общества на враждебные классы, являлся для сторонников Н. Пашича системорй чуждой и враждебной, способной разложить важнейшие институты и нормы традиционного (коллективистского и эгалитарного) уклада жизни сербского народа, привести к пролетаризации большей его части и, в конечном итоге, к национальной деградации. Богатый и агрессивный по своей природе Запад, чего они так опасались, мог превратить сербов в служащий чужим целям и не способный к сопротивлению этнографический материал.

Именно поэтому борьба Радикальной партии против австрофильского курса Милана Обреновича и правительства напредняков, которые «желали бы сразу обратить Сербию в маленькое западное государство, не обращая внимание ни на что сербское или славянское» ${ }^{33}$, отличалась предельной бескомпромиссностью. Для лидера радикалов Австро-Венгрия (оккупировавшая в 1878 г. Боснию и Герцеговину) - это не только и не столько главное препятствие на пути удовлетворения сербских национальных интересов. Это для него - парадигма Запада: экономическую и политическую экспансию Дунайской монархии он и его соратники рассматривали как наступление того самого западного капитализма, западной цивилизации, которые грозили уничтожить сербскую самобытность, сам менталитет сербского народа. Против этого-то наступления радикалы и боролись. «Главное стремление в нашей политической борьбе, - писал Пашич в марте 1887 г., - состояло в том, чтобы сохранить хорошие и соответствующие сербскому духу учреждения и воспрепятствовать введению новых западных учреждений, которые могли бы

\footnotetext{
(Напредняцкая) партии, - писал он, - сторонники западно-европейских учреждений (каждая в своей мере. - А.Ш.)», тогда как «наша партия имеет схожие черты с русско-славянской партией» (Perović, Šemjakin 1995: 238-239). См. также: Perović 2016: 62-63).

${ }^{31}$ Popper 1992: 220.

32 Trgovčević 1996: 271.

${ }^{33}$ Perović, Šemjakin 1995: 238-239.
} 
разрушить самобытность жизни нашего народа и внести смуту в народное развитие и жизнь». И далее самое важное: «Наша партия полагает, что у сербского народа есть столько хороших и здравых учреждений и обычаев, что их оставалось бы только беречь и дополнять теми прекрасными установлениями, какие находятся у русского народа и у остальных славянских племен, а с Запада брать только технические знания и науку и пользоваться ими в славяно-сербском духе» ${ }^{34}$.

В этом программном пассаже суть позитивной идеологии Радикальной партии, ключ к пониманию ее социокультурной направленности. Под «хорошими и здравыми учреждениями и обычаями» Н. Пашич имел в виду Православную церковь, крестьянскую общину и старинную традицию народного самоуправления, на которой базировалась вся политическая теория радикалов. Их он считал основными элементами восточной («славянской и православной») цивилизации. Принадлежность к ней, по мысли Пашича, помогла сербам выстоять и сохранить себя под турками. Она же должна помочь им успешно противостоять наступлению «германизма» на Балканы, резко усилившемуся после Берлинского конгресса.

Однако перед ним не мог не встать вопрос: а была ли Сербия в состоянии в одиночку бороться с этим мощным натиском «эгоистической западной культуры» ${ }^{35}$. Негативный ответ напрашивался сам собой - силы были слишком неравны. «Распространение влияния Западной Европы, - подчеркивал он в декабре 1884 г., невозможно остановить на сербской границе» ${ }^{36}$. Данная констатация подталкивала Пашича к поиску надежных союзников, Поэтому активные попытки вступить в контакт с российскими славянофильскими и официальными кругами, предпринятые им в начале 1880 -х годов (т.е. еще до эмиграции!) не кажутся чем-то неожиданным ${ }^{37}$. Они четко соотносились с его антизападнической позицией - именно в России видел Пашич оплот «славянской православной цивилизации», с которой связывал судьбу своего народа.

Здесь истоки прочного пророссийского определения лидера сербских радикалов. «Наша партия, - указывал он, - во внешней политике держалась славянской и православной России, а во внутренней политике - сербских обычаев и духа. Вот откуда происходит для многих непонятное явление, что почти весь народ тотчас же встал на нашу сторону» ${ }^{38}$. Как видим, Н. Пашич не был, подобно Стояну Новаковичу в 1890-е годы, «рациональным русофилом», как того характеризуют Л. Трговчевич и Д. Джорджевич ${ }^{39}$. Его русофильство носило более глубокий цивилизационный - характер и, как таковое, являлось «несущей опорой всей мыслительной конструкции» (Латинка Перович) ${ }^{40}$. Органично вплетясь в ткань общественной философии Пашича, оно «достроило» ее и придало ей цельность само стремление к сохранению в Сербии социального status quo и традиционных

\footnotetext{
${ }^{34}$ Ibid: 239, 241.

35 Ibid: 239.

${ }^{36}$ Šemjakin 2004: 83.

${ }^{37}$ Подробнее об этом см.: Šemjakin 2014: 47-53.

38 Perović, Šemjakin 1995: 239.

${ }^{39}$ Đorđević 1997: 369; Trgovčević 1996: 271.

${ }^{40}$ Perović 1993: 310; Id. 1995: 90.
} 
основ жизни народа («сербских обычаев и духа») неизбежно толкало его, через неприятие Запада, к поискам союза с Петербургом, как предводителем «Востока» и славянства в целом, и противовесом Вене на Балканах, в частности. В этих поисках, что особенно важно, он располагал безусловной поддержкой подавляющего большинства сербов.

Данная констатация не есть какое-то абстрактное умозаключение автора. В письме графу Н. П. Игнатьеву Пашич собственной рукой и по-русски разграничил две концепции русофильства. Оценивая поворот правительства Ст. Новаковича в сторону Петербурга, совершенный им в 1895 г., он подчеркнул: «Для России будет лестно, что все партии в Сербии теперь сторонники русского влияния. Но надо бы различать сторонников по нужде от сторонников по чувству долга и убеждениям» ${ }^{41}$.

Перед нами жесткий мировоззренческий «треугольник» - внутренний и внешний компоненты идеологии Н. Пашича туго стянуты идеей православной славянской цивилизации, которая замкнула их на себя, не давая разойтись. Столь тесное переплетение и взаимозависимость важнейших элементов превращало всю систему в монолит. Раша Милошевич в свое время точно и емко выразил тройственную суть этой системы: «Бог, народ и Россия» ${ }^{42}$, справедливо полагая, что именно в непоколебивом следовании данной триаде состояла одна из главных причин вошедшей в легенду политической «непотопляемости» Николы Пашича.

Приведенные соображения позволяют добавить еще один, синтезирующий штрих к характеристике затяжного внутрисербского конфликта конца XIX в. Он был объективен и неизбежен. Активная «проевропейская» политика Милана Обреновича ${ }^{43}$, который, по выражению академика С. Д. Сказкина, «шел напролом против своего народа» в объятия Габсбургской монархии ${ }^{44}$, не могла не ассоциироваться в столь же одномерном русофильсокм сознании его радикальных оппонентов с подрывом самих основ славянской цивилизации в Сербии, началом массированного проникновения туда «опасной западной заразы» (собственное выражение Пашича $)^{45}$. В таком принципиальном вопросе компромисса быть не могло. Тем более, что и монарх высказывался более чем определенно. «Моя забота, утверждал он, - чтобы наша сербская идея не потонула в волнах славянства» ${ }^{46}$.

Именно здесь корни того непримиримого антагонизма, столь трагически проявившегося осенью 1883 г. во время Тимокского восстания. Столкновение двух цивилизационных подходов - «западного» и «восточного» - определяло и постоянно подпитывало почти четвертьвековое противовстояние в сербском обществе, затрудняя поиск национального консенсуса в эпоху последних Обреновичей.

\footnotetext{
${ }^{41}$ ASANU, Zaostavština Nikole Pašića, 11746.

${ }^{42}$ Milošević 1926.

43 По точному замечанию Слободана Йовановича, «король Милан был весь во власти идеи-фикс, будто он и сербы - это не одно и то же; будто он - европеец, а они - балканцы, которым он должен силой навязать европейскую культуру» (Jovanović 1991: 425).

44 Skazkin 1974: 236.

${ }^{45}$ ASANU, Pašićeve hartije, 15615-1-32.

${ }^{46}$ Arhiv vnešnej politii Rossijkoj imperii (=AVPRI), Kollekcija dokumentaljnih materialov činovnikov MID-a (N. G. Gartvig), Op. 504. D. 29, L. 59.
} 
Австро-Венгрия и Россия, таким образом, всей логикой событий случившихся на Балканах после 1878 г. властно «втягивались» в самое пекло внутриполитической борьбы, становясь чуть ли не знаменами противоборствующих лагерей. Так, во время Тимокского восстания взявшиеся за оружие крестьяне встречали наступавшие королевские войска возгласами: «Долой швабов!». В ответ, тесня повстанцев, солдаты кричали: «Что помогли вам ваши русские!» ${ }^{47}$ Сл. Йованович абсолютно прав, констатируя: Петербург и Вена «являлись столь же важными „участниками“ политической жизни Сербии, что и наши собственные партии». Как таковые, они теряли в глазах участников схватки былое значение чисто внешних факторов, но кодируя различные варианты прогресса для независимого Сербского княжества (Королевства), превращались в культурные символы.

Итак, совершенно очевидно, что в отношении к России Н. Пашич был мотивирован прежде всего внутренними причинами. Он не желал для Сербии повторения пути, пройденного в ходе развития государствами Запада, пытаясь противостоять его культурному давлению на свою родину. Это обстоятельство и обусловило его мощную идеологическую (цивилизационную) привязку к России. Причем, имея в виду упомянутый выше факт, что главным аксиологическим посылом как народнической доктрины (во всех ее формах), так и славянофильского учения являлись антизападничество и стремление идти «своей дорогой», и что официальная Россия со времен Петра Великого исповедовала весьма схожую формулу прогресса, которая, по словам Джеймса Биллингтона, «позволила бы русским что-то перенять у Запада и в то же время сохранить свое отличие от него» ${ }^{48}$, понятно почему всякая Россия - царская, славнофильская, «подпольная» - являлась для него культурной опорой ${ }^{49}$.

Дабы усилить убедительность данного тезиса, приведем два высказывания Пашича. Одно - общего характера; другое (в развитие первого) - более конкретное и уточняющее некоторые важные вещи.

«Сербская задруга и сербская община - писал он на исходе 1880-х годов - очень близки русскому „миру“. Насколько они отличаются от него, настолько же отделились сербский дух и сербская философия от русского или общеславянского. Но эти институты, вкупе с некоторыми особенностями, присущими только сербскому народу, достаточны, чтобы он смог встать вровень с великой задачей славянорусского общества $<\ldots>$ и охранить себя от давления с Запада ${ }^{50}$. А в 1895 г., в беседе с известным русским педагогом Евгением Львовичем Марковым, лидер радикалов особо подчеркнул: «Нашу Радикальную партию нельзя смешивать с тем, что называется этим именем во французском парламенте; появилась она у нас со

\footnotetext{
${ }^{47}$ Dimitrijević, Ilić 2012: 66.

${ }^{48}$ Billington 2001: 26.

${ }^{49}$ Perović 2016: 62.

${ }^{50}$ Pašić 1995: 134.
} 
Светозаром Марковичем, другом ваших Чернышевского и Добролюбова; под непосредственным влиянием идей, господствовавших в России в шестидесятых годах». При этом «Маркович проповедовал только необходимость сербской общины на манер русской, чтобы не развивался у нас пролетариат, чтобы Сербии не идти в этом отношении по следам Европы ${ }^{51}$. И община у нас живет до сих пор: каждое селение имеет, помимо подворных участков, общинную землю для будущих членов своих и для общественных нужд. Об этом радикалы особенно хлопотали» ${ }^{52}$.

Оценивая последнее, поистине знаковое, заявление Пашича, Ясмина Миланович с полным правом заключает: «Тем самым и, что называется, из первых ycm (выделено нами. - А.Ш.), опровергается теория, выдвинутая Миланом Протичем (Младшим. - А.Ш.) в его книге „Радикалы в Сербии“, согласно которой образование сербской Радикальной партии, а равно ее организация и программа, рассматриваются как результат непосредствененого влияния французских радикалов ${ }^{53}{ }^{54}$. К тому же, добавим от себя, оно наглядно дезавуирует и содержащиеся в новейшей коллективной монографии сербских авторов «Сербы в 1903-1914 гг. История идей» утверждения, будто «сербские радикалы суть левое крыло либерализма» ${ }^{55}$, или дублирующее М. Протича - «сербский радикализм есть не что иное, как составная часть одноименного европейского явления, что не случайно, ибо период конца XIX начала XX в. во всей Европе представлялся современникам „золотым временем радикализма“»” побегом на мощном стволе европейского радикализма» ${ }^{57}$. И наконец, что логично: «Появление Народной радикальной партии, определявшей историю Сербии до

${ }^{51}$ В 1884 г. в письме П.А. Кулаковскому Пашич также подчеркивал, что первые сербские социалисты «страшились европейского духа и выступали за сохранение и развитие народных особенностей, дабы не идти во всем по пути Западной Европы» (ASANU, Pašićeve hartije, 14924/76 (Н. Пашић - П.А. Кулаковском. Софија, 18. марта 1884. Нацрт)). Это письмо Кулаковскому, точнее один из его черновых вариантов (оригинал и еще один черновик напечатаны в: Perović, Šemjakin 1995: 155-164), оказалось в числе рукописей Н. Пашича, переданных его внуком Николой Р. Пашичем, проживавшим в Торонто, Архиву САНУ. Недавно оно было также опубликовано (Dimitrijević, Ilić 2012: 62-66) ... Но, к сожалению, используемая нами страница письма (наиболее важная, на наш взгляд) по недосмотру «выпала» из его печатной версии. Оттого мы и цитируем ее по хранящемуся в архиве оригиналу.

52 Šemjakin 2004: 99-109; Markov 2006: 349.

53 В вышедшей в 1990 г. монографии Милана Ст. Протича (Protić 1990) красной нитью проводится мысль о том, что «радикальное движение в Сербии находилось под непосредственным влиянием политических идей французского радикализма. И более того, идеи французского радикального движения суть важнейший источник идеологии Сербской радикальной партии» (Ibid. 1990: 76). Это свое положение данный автор продолжает тиражировать и поныне. См., например: Protić M. 2006; Id. 2007.

${ }^{54}$ Milanović 2013: 138.

55 Не удивительно поэтому, что в списке циркулировавших в 1903-1914 гг. в Сербии политических идей, составленном авторами монографии, радикализм как таковой отсутствует. Зато в нем присутствует... феминизм! Противоположная точка зрения, наиболее четко и емко сформулированная Лазаром Вркатичем («Радикализм - это, без сомнения, самая значимая политическая идея в Сербии в ХІХ в., само же радикальное движение оказалось столь переломным явлением, что изменило не только политическую сферу, но и всю общественную жизнь...» (Vrkatić 2004)), с которой мы полностью солидарны, в книге не только не рассматривается, но даже не упоминается.

${ }^{56}$ Ković 2015: 11, 14.

${ }^{57}$ Ibid.: 156. 
самого 1914 г., не являлось никакой чисто сербской или русско-народнической аномалией, как полагают некоторые сербские историки» ${ }^{58}$, с которыми (Латинка Перович, Ольга Попович-Обрадович, Дубравка Стоянович), кстати говоря, мы вполне солидарны.

Тот же факт, что мнение «некоторых сербских историков», как и вывод Ясмины Миланович, на наш взгляд, единственно соответствуют реальности ${ }^{59}$, подтверждают и сами радикалы. В передовой статье их партийного органа - газеты «Одъек» («Эхо») «Сербский радикализм» от 7 мая 1889 г. читаем: «Никто не привносит радикализм в наш народ откуда-то со стороны. Напротив, он произрастает из обычного права, из совокупных общественных реалий Сербии. И прежде всего он произрастает из сербской семейной задруги». Следовательно, заключает редакция, «корень сербского радикализма лежит в самом народе, в его правовых понятиях и обычаях (здесь и далее выделено в оригинале. - А.Ш.). За фасадом писанной конституции всегда существует в нашем народе конституиия неписанная, основанная на обычае, которая и должна быть фундаментом той - официальной» ${ }^{60}$. Именно поэтому, как нам кажется, великий сербский этнолог Йован Цвийич удивительно тонко заметил, что «сербский радикализм - это настолько же этнопсихическое явление, насколько и политическое...» ${ }^{61}$.

Ну, а теперь, в свете сказанного выше, совсем кратко обратимся непосредственно к Николе Пашичу - лидеру радикалов и «олицетворению» радикализма. В упомянутой новой книге сербских коллег он назван одним из идеологов «радикального, демократического либерализма» европейского типа (наряду с Владимиром Йовановичем, Светозаром Марковичем [?!], Йованом Скерличем $)^{62}$.

Между тем, как заметил ученик Й. Цвийича, видный этно- и социо-психолог Владимир Дворникович, «политический тип и мораль Николы Пашича были органично связаны с той социально-психологической средой, представителем которой он оказался» ${ }^{63}$. А потому совсем не случайно, что, по словам российского посланника в Сербии князя Г. Н. Трубецкого, «он так олицетворял свою Сербию, как ни один человек в Европе не олицетворял своей страны» ${ }^{64}$. Независимо от русского дипломата к весьма схожей мысли пришел и его итальянский коллега, граф Карло Сфорца, много общавшийся с Пашичем и написавший о нем целую книгу: «Чем

\footnotetext{
58 Ibid.: 179.

${ }^{59}$ Озвученная в разговоре с русским педагогом позиция Пашича, к примеру, лишь подтверждает давнюю мысль Л. Перович: «Радикальная партия выросла из социалистического движения, <..> которое утвердило идеологию неповторения западно-европейского пути - по определению антикапиталистическую и антилиберальную (выделено нами. - А.Ш.)» (Perović 2006: 20). Тем самым вождь сербских радикалов сам выбивает почву из-под ног тех коллег, кто относит их к числу левых либералов, как авторы «Сербов в 1903-1914 гг.», или, еще шире, «либеральных политических партий» вообще, как, например, Никола Жутич (См.: Žutić 2007: 41, 48-48).

${ }^{60}$ Srpski radikalizam, Odjek. Nr. 66. 7. мaj 1889.

${ }^{61}$ Cvijić 1999: 64.

62 Ković 2015: 156.

${ }^{63}$ Dvorniković 1939: 881.

${ }^{64}$ Trubeckoj 2006: 613.
} 
дольше я работал над ней, тем больше отдавал себе отчет в том, что о Николе Пашиче невозможно писать, не думая постоянно об истории и характере его народа» ${ }^{65}$.

И здесь встает резонный вопрос - как сам Пашич оценивал «характер его народа». Возвращаясь после переворота 29 мая 1903 г. из Опатии в Белград, он дал интервью редактору выходившей в Загребе газеты «Србобран» («Защитник сербов»). На его вопрос: «Можно ли было предвидеть, что дело кончится такой катастрофой?» радикальный лидер ответил: «Вы знаете, что в последнее время в Сербии происходил переворот за переворотом, законы принимались и отменялись, конфликт сменялся конфликтом. Мы, сербы, <..> не то что западные народы (выделено нами. - А.Ш.), тут же протестующие против нарушения закона и наступления реакции! Как люди более пассивной природы, мы допускаем, чтобы грехи верхов копились, пока не рванет <..>. Политика покойного короля Александра неминуемо должна была привести к катастрофе» ${ }^{66}$.

Ну, а после Майского путча и ликцидации Обреновичей радикалы пришли к власти «всерьез и надолго». Судьбы Королевства вплоть до Мировой войны вершили Никола Пашич, - этот, по точной дефиниции Л. Д. Троцкого, «абсолютный властитель Сербии» ${ }^{67}$, и его радикальная генерация. «В Белграде, - продолжал будущий „соавтор“ российского Октября, - все политические разговоры вертятся вокруг личности Пашича <..>. Про короля Петра вспоминают только в исключительных случаях, да и то по чисто внешним поводам. А Пашич всегда у всех и на уме и на языке. Он думает за всех, он знает, что нужно» ${ }^{68}$.

Кстати, страной Николай Петрович (как его звали в России) управлял так же, как собственным домом, всегда оставаясь с ней, а не над ней. Тот же князь Г. Н. Трубецкой, имевший возможность часто видеть премьера в военные годы, вспоминал: «С раннего утра Пашич отправлялся в министерство и с небольшим перерывом сидел там целый день. Фактически он был распорядителем судеб Сербии и решал все крупные и мелкие дела. Он достигал этого не только благодаря своему официальному положению, но и громадному личному авторитету». И далее: «Члены кабинета были много моложе Пашича. Он смотрел на них, как на молодых людей, говорил им “ты” и звал по уменьшительному имени. Это было вполне в нравах патриархальной Сербии. В Нише (временной сербской столице в 1914-1915 гг. А.Ш.) все министры занимались в одной большой зале. Пашич сидел в другом углу комнаты за общим столом. Получалось впечатление профессора и учеников». И, наконец: «Он правил Сербией наподобие сельского старосты в большом, но малоустроенном селе. Зная всех и каждого, он ловко умел устранить политическое соперничество <..>. Всего более (а это уж точно маленький шедевр! - А. Ш.) напоминал он мне сельского старосту в своих отношениях с богатой помещицей Россией. Он знал, что помещица может наехать, рассердиться и накричать, а он молча потрет себе бороду, а потом еще выхлопочет своему селу и деньжонок, и леску на

\footnotetext{
65 Sforca 1937: 287.

66 Višnjić 2013: 150; На это интервью Н. Пашича в Загребе наше внимание любезно обратила Латинка Перович, за что мы выражаем ей искреннее признание.

${ }^{67}$ Trockij 2011: 71.

${ }^{68}$ Ibid.: 67.
} 
хозяйство» ${ }^{69}$.

Профессор международного права и одновременно корреспондент «Нового времени» А. А. Пиленко также оставил свидетельство о встрече с Пашичем в ходе войны: «В январе прошлого года я посетил Ниш и был принят главой сербского правительства <..>. Нечего, конечно, говорить о той популярности и любви, которыми пользуется в стране этот выдающийся государственный деятель. К нему идут, как к отцу, и двери его кабинета открыты для всех. Он не только глава правительства, но он друг, с которым советуются обо всем, к голосу которого прислушиваются» ${ }^{70}$.

Такая власть своего «старосты» (или «отца») вполне устраивала сербского селяка, который даже в самые тяжелые минуты фаталистически замечал: «Байя знает, что делает» («Зна Баја шта ради!»), а значит - все образуется.

В свое время Макс Вебер выделил важнейший критерий «харизматического типа господства» - он опирается на «личные отношения между господином и подчиненным», противостоя «формально-рациональному типу господства, как безличному» ${ }^{71}$. Случай с Пашичем наглядно подтверждает истинность данной мысли.

Таким образом, национальное согласие вызревало в Королевстве после 1903 г. на базе традиционно-патириархальных понятий о власти, ее носителях и их политической культуре, в рамках которых предпочтение отдавалось скорее обычаю, чем закону ${ }^{72}$. Где же здесь европейский «радикальный и демократический либерализм» Пашича или режим «либеральной демократии», якобы восторжествовавший в Сербии при короле Петре Карагеоргиевиче, как считает коллега Милош Кович ${ }^{73}$ ? Прав Д. Николаевич: Никола Пашич - «был носителем нашего, специфически нашего, демократизма» ${ }^{74}$. Ведь еще в середине XIX в. признанный классик Алексис де Токвиль обратил внимание на возможный плюрализм демократических режимов. «Демократические общества, - писал он, могут быть либеральными и могут быть деспотическими. Они могут и должны приобретать разный характер в Соединенных Штатах или Европе, в Германии или во Франции» ${ }^{75}$. А уж тем более к западу от Эльбы или на Балканах, добавим от себя...

Мы рассмотрели внутреннюю (социокультурную) мотивацию русофильства Николы Пашича. Теперь пришла пора хотя бы кратко обратиться к внешнеполитической (национальной) его стороне, хотя она и так более чем очевидна для всех. Однако, не все столь просто!..

Все дело в том, что в условиях незавершенности процесса «освобождения и

\footnotetext{
${ }^{69}$ Trubeckoj 2006: 611-613.

${ }^{70}$ Diplomaticus 17/30 aprelja 1916 g.

${ }^{71}$ Gajdenko 1990: 28.

72 Подробнее об этом см.: Šemjakin 2009: 7-31; Id. 2016: 187-194.

${ }^{73}$ Ković 2015: 185.

${ }^{74}$ Nikolajević 1927: 45.

${ }^{75}$ Цит. по: Aron 1993: 227.
} 
объединения» стремление сохранить сербский народ от влияния Европы и социального расслоения не являлось для Н. Пашича самоцелью. Защита патриархальной модели «народ - сообщество равных» становилась для него средством и формой внутренней консолидации жителей Сербии, поскольку малая расщепленность интересов внутри социума позволяла сохранять единство народного духа и высокую степень его мобилизационной готовности - важнейшую внутреннюю предпосылку будущего освобождения. Социальное равенство, таким образом, отождествлялось в его глазах с национальным единством ${ }^{76}$. Причем такое отождествление почти всегда «санкционировалось» снизу, следствием чего было то, что «героическое» начало закладывалось в поведенческий код населения с младых ногтей («С ранних лет ребенок воспитывался как воин и мститель, в лютой ненависти к врагу» ${ }^{77}$ ) - мотив грядущей войны за «отмщение Косова» и необходимости подготовки к ней с самого «нежного» возраста тиражировался на всех уровнях: в семье, школе, сельском локусе, Народной скупщине ${ }^{78}$, поскольку считалось, процитируем Й. Цвийича, - что «сербская проблема должна быть разрешена силой» ${ }^{79}$.

И Пашич был совершенно прав в своих расчетах: вспоминая о настроениях, царивших в Сербии накануне Балканских войн, интеллектуал и политик Милан Грол особо подчеркивал «инстинктивное единение национально и соџииально однородной массы (выделено нами. - А. Ш.), ее исключительную уверенность в себе, которая всегда возникает там, где чувствуется, что, стоя плечом к плечу, она составляет единый монолит» ${ }^{80}$.

О том же, что реализация «заветной мысли сербской» (об освобождении и объединении сербов) всегда была для него задачей первейшей и приоритетной, свидетельствует он сам. В 1902 г. в своей «Политической исповеди» лидер радикалов буквально отчеканил: «Национальная свобода всего сербского народа всегда была для меня высшим идеалом, чем гражданская свобода сербов Королевства» ${ }^{81}$. А год спустя, в загребском интервью, отвечая на вопрос: «За что выступает большинство министров, членов Народной скупщины и Сената - за монархию или республику, ибо ходят упорные слухи о разделенности мнений относительно формы правления в Сербии?», он подчеркнул: «Огромное большинство - за монархическую систему, так как республика для нас - это слишком рано. Будь в Сербии республиканская форма правления, она бы подверглась мощным иностранным влияниям, что явилось бы самым большим злом. Ведь перед страной стоит не только задача ее внутреннего переустройства, но и заветная сербская мысль. Создать республику означало бы распроститься с этой заветной мыслью. И как монархии, Сербии едва удается бороться с иностранными влияниями. А кроме того, есть немало сербов, которые не умеют пользоваться полной и неограниченной свободой, поскольку еще не научились

\footnotetext{
${ }^{76}$ Perović 1995: 90; Perović 2016: 69-71.

${ }^{77}$ Id. 2006: 64.

${ }^{78}$ Cм: Šemjakin 2006: 292-313; Id. 2015: 11-43.

${ }^{79}$ Цит. по: Naumović 2015: 694.

${ }^{80}$ Grol 1939: 13.

${ }^{81}$ Pašić 1989: 129.
} 
ее уважать» ${ }^{82}$.

Последняя фраза весьма примечательна - особенно в свете чем дальше, тем более отдаляющихся от исторической реальности мифологем отдельных сербских историков ${ }^{83}$.

Итак, думается, можно констатировать, что внутренний и внешний компоненты идеологии Николы Пашича представляли собой нерасторжимое единство, вследствие чего и Россия в его восприятии проявлялась в двух ипостасях: с одной стороны, как гарант сербской самобытности (или, по его собственным словам, «сербских обычаев и духа») в условиях натиска «опасной западной заразы», a с другой - как мощный союзник в деле будущего «освобождения и объединения».

Поэтому нам кажется вполне обоснованной «интегральная» формула его русофильства, предложенная в монографии Дж. Станковича: «Россия была необходима Пашичу в первую очередь для укрепления реальной независимости Сербского государства и его славянской идентичности (выделено нами. - А. Ш.), которые оказались под ударом в результате немецкого проникновения на Восток. С другой стороны, он видел в ней великую державу - опору сербов в решении их национального вопроса» ${ }^{84}$. Двадцать лет спустя схожую мысль высказала и О. Попович-Обрадович: «Безграничная лояльность Пашича к России, особенно ярко проявившаяся после 1903 г., - факт совершенно неоспоримый. Она выражалась как в его культурно-цивилизационном определении, так и во внешнеполитической ориентации» ${ }^{85}$.

\footnotetext{
${ }^{82}$ Višnjić 2012: 151.

83 Ср., например, с утверждением М. Протича-Младшего: «Сербский народ, в огромном своем большинстве неграмотный и необразованный, обладал такой политической зрелостью и знанием, что мог самостоятельно принимать правильные и мудрые решения в своих интересах (?! - A.Ш.)» (Protić 2008: 7).

${ }^{84}$ Stanković 1985: 80.

${ }^{85}$ Popović-Obradović 2015: 408 (впервые сочинение О. Попович-Обрадович было опубликовано в 2004 г.);

Cp. с «конструкцией» Предрага Марковича: «Необходимо разделять внутри- и внешнеполитическое определение от цивилизационных воздействий. Смешение этих двух сфер, по-видимому, и привело к тому, что заблуждение о русском влиянии в Сербии имеет столь широкое хождение. Русофильская политическая ориентация совсем не обязательно имела под собой антизападническую культурную основу». И далее: «Вербальное антизападничество Светозара Марковича и радикалов в период форми рования их программы, не привело к какому-нибудь регрессу в хозяйственном и культурном развитии. Сербская элита все более поворачивалась к Западу...». Главный вектор идейного «разворота» всей элиты, таким образом, определен! Но в то же время, вынужденный признать, что «у Пашича, видимо, все-таки имелись элементы веры в „славянскую цивилизацию“», автор должен был связать концы с концами. И потому, под его пером, «Россия играла роль переносчика ценностей западной цивилизации (?! - A.Ш.): как в области социально-экономических процессов, так и, отчасти, в культуре» (Marković 1996: 593-595)
} 


\section{2. Из истории взаимоотношений}

«Лично Вам, Николай Петрович, слава и привет!»

(М.В. Челноков, московский городской голова)

А теперь, переходя от теоретической части настоящей статьи к практической, приведем несколько цифр и дат. По нашим подсчетам, за свою жизнь Никола Пашич побывал в России (официально и неофициально) не менее 13 раз, причем в 1893-1894 гг. провел в ней целый год в должности посланника Сербии. В первый раз он прибыл в Империю, оказавшись в Петербурге и Москве, в декабре 1885 г. еще в бытность свою политическим эмигрантом в Румынии. Примерно к этому времени (конец 1885 - 1887 гг.) относится и обретение им полного доверия со стороны русских общественных (славянофильских) кругов, чему в огромной степени способствовал опальный митрополит Михаил, в 1884-1889 гг. проживавший в России (Киев, Москва $)^{86}$. В том же (1885) году мы фиксируем и первый «знак внимания» к Пашичу официальных российских властей ${ }^{87}$. Дальше - больше: в феврале 1890 г., находясь в должности председателя Народной скупщины Сербии, Пашич впервые посетил Петербург с официальным визитом, во время которого был принят императором Александром III, получил свой первый русский орден - святого Станислава I степени и 80 тыс. винтовок-берданок в дар Королевству ${ }^{88}$.

Но гораздо более важным явилось другое. В начале 1890-х годов началась смена «русских фаворитов» в Сербии. Звезда Йована Ристича - неприкосновенного до этого «любимца» Петербурга начала закатываться. Он терял доверие императорского правительства. На смену ей стремительно восходила «звезда по имени Пашич». Ристич волновался и строил интриги. Но русские уже сделали ставку на новую фигуру. В 1894 г. Алимпие Васильевич - ближайший соратник Ристича по Либеральной партии и сербский посланник в России пытался, как мог, облить грязью Пашича (с целью сбить его растущее влияние) в глазах русского истэблишмента. «Сербские патриоты не могут простить грех сербу, поднявшему руку на свое Отечество (речь шла о деятельности Пашича в эмиграции в 1883-1889 гг. - А. Ш.); ему и друзья Сербии не смеют подавать руки, - доносил он шефу. - Все со мной соглашались, кроме военного министра, который защищал Пашича, повторяя, что он шел не против Сербии, но против Милана» ${ }^{89}$. Министр военный, Петр Семенович Ванновский, старый соратник Александра III, с которым они вместе «ломали» балканскую кампанию 1877-1878 гг., был прав. Отношение российской верховной власти к Николаю Петровичу не изменилось...

Мы могли бы очень долго рассказывать почти о каждой поездке Николы Пашича в Россию. Но на этот раз ограничимся лишь одной - последней, состоявшейся весной 1916 г. С одной стороны, в этом году ей исполнилось точно 100 лет, С другой же, она

\footnotetext{
${ }^{86}$ Подробнее об этом см.: Šemjakin 2003: 219-238.

${ }^{87}$ См.: Id. 1992: 131-143.

${ }^{88}$ См.: Id. 2015: 65-68.

${ }^{89}$ ASANU, Fond Jovana Ristića, inv. br. 10/218; sign. X/7.
} 
оказалась для Пашича «триумфом и трагедией». Триумфом, имея в виду то, как его встречали везде в России; трагедией же потому, что страна, столь тепло его принимавшая, менее через год перестала существовать!

Как известно, в январе 1916 г. завершилась трагическая «Сербская Голгофа» мученический, часто в снежную метель и без куска хлеба, переход остатков сербской армии и части гражданского населения через албанские горы на побережье Адриатики с последующей эвакуацией на Корфу. В элите Королевства царило уныние, перешедшее, по прибытии на благословенный ядранский остров, в перепалку и взаимные обвинения - кто виноват в постигшей Сербию катастрофе? Принц-регент Александр Карагеоргиевич принял меры. Начальник Генерального штаба, воевода Радомир Путник под предлогом болезни был смещен и отправлен на пенсию; свои посты потеряли и его заместитель полковник Живко Павлович, а также военный министр Радивое Бойович. Зашаталась почва и под Пашичем - движимый ревностью к нему, престолонаследник начал подумывать о новом, военном кабинете во главе с героем Колубарской битвы, воеводой Живоином Мишичем. Однако разменявший восьмой десяток, старый политический лис Пашич все четко фиксировал и, пытаясь защитить себя, вытащил неубиенную карту - объявил о необходимости визита в Россию. На первый взгляд, связь непонятная, однако, она присутствует и теснейшая.

Итак, ранней весной 1916 г. сербский престолонаследник выехал в поездку по столицам государств - членов Антанты. Его сопровождал Пашич. Рим, Париж и Лондон они посетили вместе, но в Петроград с берегов Темзы премьер отправился один. Уж очень он рвался туда. Но зачем?

Уже говорилось, что Россия всегда являлась для него самой мощной и надежной опорой. Причем не только ее официальные круги во время правления Александра III и Николая II, но и русское общество. В подтверждение последнего приведем лишь один пример. Спрашивается, - с кем и чем ассоциировалась Сербия в глазах русского образованного слоя в начале XX в.? Видный сербский ученый-славист, академик САНУ, но при этом русская по рождению, Ирена (Ирина Георгиевна) ГрицкатРадулович вспоминала о своей матери, далекой от всякой политики (она завершила в Петербурге консерваторию, а в Белграде преподавала музыку в школах «Стеван Мокраняц» и «Корнелие Станкович»): «Все, что мать раньше (т.е. до эмиграции. А.Ш.) знала о Сербии - это был Дунай с притоками Савой, да Моравой, затем города Белград и Ниш, король Петр и министр Пашич» ${ }^{90}$.

И тот прекрасно знал о таком к себе отношении, сложившемся за десятилетия его собственного последовательного «русофильства» (как в политике, так и в жизни). Именно поэтому, в трудную для себя минуту, он и рассчитывал на него. Таким образом, можно констатировать, что одним из важнейших мотивов его стремления в Россию весной 1916 г. было желание укрепить пошатнувшееся положение и

${ }^{90}$ Grickat-Radulovič 2014: 519. 
«подчеркнуть, - как о том злобно выразился завистливый престолонаследник Александр, - свой международный вес» ${ }^{91}$.

16 апреля 1916 г. Никола Пашич прибыл в Петроград. Отношение к нему в России было ожидаемо доброжелательным и почти семейным, хотя следует сказать, что вечно опасавшийся чего-то министр иностранных дел С. Д. Сазонов поначалу косо смотрел на визит сербского премьера: «Считаю, что приезд его, - писал он послу в Риме А. А. Гирсу, - при настоящих обстоятельствах может вызвать здесь нежелательный шум» ${ }^{92}$. Однако, Гирс встал на сторону Пашича: «Очень опасаюсь, что $<\ldots>$ отклонение его поездки произведет на него тяжелое впечатление» И далее: «Позволю себе высказать, что < . .> едва ли удобно отклонять его приезд в Петроград, тем более, что в настоящую минуту едва ли возможно предполагать возбуждение щекотливых вопросов» ${ }^{93}$. И министр сдался. В Париж и Рим, для передачи посланнику в Сербии князю Г. Н. Трубецкому, полетела телеграмма: «Можете передать Пашичу, что препятствий к его приезду не встречается...» ${ }^{94}$. Мы уверены, что в резкой смене настроения Сазонова сыграл роль и Николай II, судя по его личному вниманию к сербскому гостю, о чем ниже.

Итак, повторимся, встретили Пашича как родного. Во-первых, он прибыл в Россию как гость русского правительства, и все расходы по его пребыванию взяло на себя министерство императорского двора, что было утверждено императором ${ }^{95}$. И далее, он предполагал пробыть здесь всего пять дней, и только в Петрограде, дабы, по его собственным словам, «благодарить за поддержку и иметь личное общение с ответственными руководителями» ${ }^{96}$. Однако, вместо этого провел «в гостях» почти месяц, приняв любезное предложение государя побывать, кроме Питера, в Москве и в Одессе, где тогда формировалась Сербская добровольческая дивизия.

18 апреля в здании на Певческом мосту Пашич провел переговоры с министром С. Д. Сазоновым и остался ими полностью удовлетворен. Русские поддержали сербов в главном - в признании необходимости наказания Болгарии за октябрьское предательство 1915 г. А 20 апреля сербский премьер получил от императора орден святого Владимира первой степени - награду очень почетную и редкую. Таким образом, очевидно, что столь высокое отличие явилось проявлением особого благоволения Николая II к нему.

На следующий день, 21 апреля, последовал очередной знак высочайшего внимания. В 11 часов утра Пашич был принят императором в Царском Селе, а затем (вместе со своим заместителем по министерству иностранных дел, секретарем и сербским посланником в России М. Спалайковичем) приглашен к завтраку в кругу царской семьи. В архиве сохранился план стола из малой библиотеки Александровского дворца, за которым располагались все участники. Он весьма показателен. Кроме императорской четы, великих княжен (Татьяны, Марии, Ольги,

\footnotetext{
91 Draškić 1990: 157.

92 AVPRI, Fond Politarhiv (1916), D. 4024, L. 20 (2/15 марта 1916 г.).

${ }_{93}$ Id. L. 21-22 (А.А. Гирс - С.Д. Сазонову. Рим, 4/17 марта 1916 г. № 257, 258).

${ }_{94}$ Id. L. 23 (С.Д. Сазонов - А.П. Извольскому и А.А. Гирсу. Петроград, 6/19 марта 1916 г.)

${ }^{95}$ Rossijskij gosudarstvennij istoričeskij arhiv (=RGIA). F. 472. Op. 60. D. 2300. L. 3 ob. - 4.

${ }^{96}$ AVPRI, F. Politarhiv (1916 g.), D. 4024, L. 22 (А.А. Гирс - С.Д. Сазонову. Рим, 4/17 марта 1916 g.).
} 
Анастасии) и наследника Алексея Николаевича, а также нескольких придворных и сербской делегации, на завтраке не было ни одного официального лица, что наглядно показывает его приватную, почти интимную, природу ${ }^{97}$.

Все это совсем не случайно. Ведь еще будучи наследником (в 1893 г.) Николай II лично познакомился с Пашичем - тогда посланником Сербии в России ${ }^{98}$. История донесла и его интегральную оценку сербского премьера, данную пятнадцать лет спустя, в 1908-ом: «Пашич - это опора здравой политики Сербии» ${ }^{99}$. Во время известной аудиенции 20 января 1914 г. император обещал ему: «Мы все сделаем для Сербии!» ${ }^{100}$, что благородно и исполнил всего через полгода. И Пашич тогда же лично обратился к монарху по крайне деликатной теме - о возможной женидьбе престолонаследника Александра на одной из его дочерей ${ }^{101}$. Черновик этого обращения на русском языке (разговор шел наедине, и «проситель» к нему тщательно готовился) сохранился. Как видим, сербский и русский «тезки» давно знали и уважали друг друга, разумеется, - каждый по-своему и на своем уровне.

Не отставало от императора и петроградское общество. 25 апреля в ресторане гостиницы «Астория» в его честь был устроен банкет с присутствием трехсот приглашенных. В тот же день Петроградский комитет помощи Сербии передал Пашичу 70 тыс. рублей ${ }^{102}$.

В Москве посланец маленького, но не сдавшегося врагу народа был встречен с еще большим восторгом. 28 апреля в 10 часов утра на Николаевском вокзале городской голова М. В. Челноков, по словам московских газет, «поднес ему по русскому обычаю хлеб-соль на серебряном блюде в древнерусском стиле, украшенной камнями с такой же солоницей. На блюде надпись: „От московского городского общественного управления 28 апреля 1926 г. министру-президенту Сербии Николе Пашичу“» ${ }^{103}$. А 29 апреля в «Метрополе», чтобы его приветствовать и угостить, собралось уже шестьсот человек! Причем даже меню банкета здесь было выдержано в духе «манифестации»: «Суп славянский. Бульон московский. Филе из судака по-чешски. Жаркое. Салат по-сербски. Соуса: польский и хорватский» ${ }^{104}$. В этом вся Первопрестольная - широкая, хлебосольная, славянская. Не то, что чопорный «европейский» Питер - с его «кремом шампиньон» и «севрюгой поанглийски», чем закусывали в «Астории» ${ }^{105}$.

Накануне же вечером, по случаю приезда сербского премьера, Московская

\footnotetext{
${ }^{97}$ RGIA, F. 473, Op. 3. D. 1939, L. 3.

${ }_{98}$ Gosudarstvennij arhiv Rossijskoj Federacii, F. 601, Op. 1. D. 1587, L. 33 ob; Известный столичный публицист И. Родионов, нередко встречавшийся с Пашичем во время его наездов в Петербург, вспоминал в эмиграции, как в 1900 г., вернувшись с высочайшей аудиенции, тот был в полном восторге от отношения к нему Николая II: «Он встретил меня как брата, со своей чудесной улыбкой. Вспоминал наши встречи в Аничковом дворце в бытность свою престолонаследником...» (Rodionov 1937).

${ }^{99}$ Popović D. 1937: 146.

100 Pašić 2011: 233.

101 Ibid.: 232-233.

102 Novoe vremja, 26 aprelja/9. maja 1916 g.

${ }^{103}$ Ranee utro, 29. aprelja 1916 g.

${ }^{104}$ Arhiv Srbije (AS), Zaostavština Nikole Pašića (nesređena građa).

105 Ibid.
} 
городская дума провела «экстренное» заседание, которое единогласно постановило: «Ассигновать из средств Московского городского управления в распоряжение Николы Петровича Пашича на нужды разоренного войной сербского народа сто тыс. рублей» ${ }^{106}$. Под бурные овации наш герой по-русски подписал расписку в получении пожертвования: «Николай Петрович Пашич. Министр-председатель Сербский» ${ }^{107}$

А русское общество продолжало жертвовать в пользу сербов. Московский славянский комитет вручил Пашичу 50 тыс. рублей ${ }^{108}$, Губернская земская управа 10 тыс. ${ }^{109}$. Позднее, когда сербский премьер отправился из Москвы в Одессу для инспекции Добровольческой дивизии, он (во время остановки в Киеве) получил от киевских городских властей еще 25 тысяч ${ }^{110}$, а от одесских - все $30^{111}$.

14 мая 1916 г., после посещения сербских добровольцев в Одессе, Никола Пашич, в прекрасном расположении духа и словно заново политически родившись, покинул свою верную защитницу Россию и кружным путем (через Париж и Ниццу) выехал на Корфу. Все впереди казалось светлым и радужным, в чем, кстати, он не сильно заблуждался - в январе 1917 г. сербский посланник в Лондоне Йован Йованович записал в дневнике: «Из всех сербских дипломатов один только Пашич пользуется в России неограниченным доверием» ${ }^{112} \ldots$ Но, неисповедимы пути Господни, и очень скоро Михаил Васильевич Челноков, еще совсем недавно возглашавший Николаю Петровичу с трибуны Мосгордумы «славу и привет» ${ }^{113}$, напишет ему в Белграде расписку в получении 10 тысяч динаров беженской помощи ${ }^{114}$. Однако это уже другая история!

\section{REFERENCES:}

Sources:

Arhiv Srbije

Zaostavština Nikole Pašića (nesređena građa)

Arhiv Srpske akademije nauka i umetnosti, Beograd

Pašićeve hartije

Fond Jovana Ristića

Arhiv vnešnej politii Rossijkoj imperii

Kollekcija dokumentaljnih materialov činovnikov MID-a (N. G. Gartvig) Op. 504.

Fond Politarhiv (1916 g.)

Gosudarstvennij arhiv Rossijskoj Federacii - Fond 601

Rossijskij gosudarstvennij istoričeskij arhiv - Fond 472

106 Šemjakin, Ivanova, Perišič, Timofeev, Miloradovič 2012: 344

${ }^{107} \mathrm{Ibid.}$ (иллюстрации).

${ }^{108} \operatorname{Reč}, 30$ aprelja 1916 g.

${ }^{109}$ Ibid.

${ }^{110}$ Russkie vedomosti, 3 maja $1916 \mathrm{~g}$.

111 Novoe vremja, 5/18 maja $1916 \mathrm{~g}$.

112 Jovanović 2015: 235.

113 Šemjakin et al 2012: 346.

${ }^{114}$ Arhiv Srbije (AS), Zaostavština Nikole Pašića (nesređena građa). 
Rukopisno odeljenje Matice srpske, Novi Sad

Zaostavština Milana Jovanovića-Stojimirovića

References:

Aron, R. Etapi razvitija sociologičeskoj misli, Moskva: Nauka, 1993. (Russian Cyrillic)

Billington, D. Ikona i topor. Opit istolkovanija istorii russkoj kuljturi, Moskva: Rudomino, 2001. (Russian Cyrillic)

Cvijić, J. Jedinstvo i psihički tipovi dinarskih južnih Slovena, Beograd: Slobodna knjiga, 1999.

Dimitrijević, B. i Ilić J. (prir.). Nikola Pašić: zaostavština iz Toronta: 1876-1903, Zaječar: Zadužbina Nikole Pašića, 2012. (Serbian Cyrillic)

Diplomaticus. „Nikola Pašič“, Novoe vremja, 17/30 aprelja 1916; 26 aprelja/9. maja 1916; 5/18 maja 1916 (Russian Cyrillic)

Dvorniković, V. Karakterologija Jugoslovena, Beograd: Kosmos, 1939. (Serbian Cyrillic)

Draškić, P. Moji memoari (prir. D. Bataković), Beograd: Srpska književna zadruga, 1990. (Serbian Cyrillic)

Đorđević, D. Portreti iz novije srpske istorije, Beograd: Beogradski izdavačko-grafički zavod, 1997. (Serbian Cyrillic)

Gajdenko, P. P. „Sociologija Maksa Vebera“, u: M. Veber, Izbrannie proizvedenija, Moskva: Nauka, 1990. (Russian Cyrillic)

Gavrilović, M. Narodni put: odabrani spisi, Novi Sad: Balkanija, 2015. (Serbian Cyrillic)

Grebenac, S. „Državništvo Nikole Pašića“, u: Nova Evropa, XIII, 1926. (Serbian Cyrillic)

Grickat-Radulovič, I. G. „Na zarubežnoj rodine“, u: A. L. Šemjakin (prir.), Russkie o Serbii i serbah, II (arhivnie materiali), Moskva: Indrik, 2014. (Russian Cyrillic)

Grol, M. Iz predratne Srbije: utisci i sećanja o vremenu i ljudima, Beograd: Srpska književna zadruga, 1939. (Serbian Cyrillic)

Ivković, M. „Veliki državnik - neumorni političar“, u: Pašić: illustrovani radikalni almanah: građa za pedesetogodišnju istoriju Narodne radikalne stranke i političku istoriju Srbije, 3. Beograd: bez izdavača, 1926. (Serbian Cyrillic)

Jelačić, A. Rusija i Balkan: pregled političkih i kulturnih veza Rusije i balkanskih zemalja 866-1940, Beograd: Francusko-srpska knjižara A. M. Popovića, 1940. (Serbian Cyrillic)

Jovanović, J. Dnevnik (1896-1920), (prir. R. Ljušić i M. Milošević), Novi Sad/Beograd: Prometej/Radio-televizija Srbije/Arhiv Jugoslavije, 2015.

Jovanović, S. Sabrana dela Slobodana Jovanovića, 11, Beograd: Beogradski izdavačko-grafički zavod/Jugoslavijapublik/Srpska književna zadruga, 1991. (Serbian Cyrillic)

Kazimirović, V. Nikola Pašić i njegovo doba (1845-1926), 1, Beograd: Nova Evropa, 1990. (Serbian Cyrillic)

Ković, M. (prir.), Srbi 1903-1914: istorija ideja, Beograd: Clio, 2015. (Serbian Cyrillic)

Markov, E. L. „Putešestvija po Serbii i Černogorii. Putevie očerki“, u: A. L. Šemjakin (prir.). Russkie o Serbii i serbah, I (pisma, statii, memuari), Sankt-Peterburg: Aleteja, 2006. (Russian Cyrillic)

Marković, P. „Stav prema Zapadu u srpskoj modernoj istoriji“, u: S. Terzić (ur.). Evropa i Srbi, Beograd/Novi Sad: Istorijski institut SANU/Pravoslavna reč, 1996. (Serbian Cyrillic)

Milanović J. Apostoli radikalizma: život i delo Pavla Paje Mihajlovića (1845-1915), Beograd: Službeni glasnik, 2013. (Serbian Cyrillic)

Milošević, R. „Nikola Pašićc, Politika, br. 6693, 10. decembar 1926.

Naumović, S. ,Jovan Cvijić“, u: M. Ković (ur.). Srbi 1903-1914: istorija ideja, Beograd: Clio, 2015. (Serbian Cyrillic)

Nikolajević, D. „U čemu je smisao N. Pašića“, u: Pašić: illustrovani radikalni almanah:građa za pedesetogodišnju istoriju Narodne radikalne stranke i političku istoriju Srbije, 4, Beograd: bez 
izdavača, 1927. (Serbian Cyrillic)

Pašić, N. „Moja politička ispovest“, u: Stojković, M. (ur.) Serbia i komentari 1988-1989, Beograd:

Zadužbina Miloša Crnjanskog, 1989. (Serbian Cyrillic)

. Sloga Srbo-Hrvata, Beograd: Stubovi kulture, 1995. (Serbian Cyrillic)

. „Audijencija kod ruskog cara Nikole II“, u: Jovanović, M. Srbi o Rusiji i Rusima: od

Elizavete Petrovne do Vladimira Putina (1750-2010): antologija, Beograd: Glasnik, 2011. (Serbian Cyrillic)

Perović, L. „V. Kazimirović, Nikola Pašić i njegovo doba (Beograd, 1990)“, Istorijski časopis, 39, 1992. (Serbian Cyrillic)

. Srpsko-ruske revolucionarne veze: prilozi za istoriju narodnjaštva u Srbiji, Beograd:

Službeni list SRJ, 1993. (Serbian Cyrillic)

. Srpski socijalisti 19. veka, 3, Beograd: Službeni list SRJ, 1995. (Serbian Cyrillic)

. (prir.). Nikola Pašić u Narodnoj skupštini, 1, Beograd: Službeni list SRJ, 1997. (Serbian

Cyrillic)

. Između anarhije i autokratije: srpsko društvo na prelazima vekova (XIX-XXI), Beograd:

Helsinški odbor za ljudska prava, 2006.

. „Srpsko-ruske istorijske analogije“, u: Potka srpskog identiteta: antizapadnjaštvo, rusofilstvo, tradicionalizam..., Beograd: Res publika, 2016.

Perović, L. i Šemjakin A. (prir.). Nikola P. Pašić: pisma, članci i govori (1872-1891), Beograd: Službeni list SRJ, 1995. (Serbian Cyrillic)

Popović, D. „Nikola Pašić i Rusija“, Godišnjica Nikole Čupića, 46, 1937. (Serbian Cyrillic)

Popović, N. „Rusofilstvo Nikole Pašića“, u: Nikola Pašić: život i delo, Beograd: Zavod za udžbenike i nastavna sredstva, 1997. (Serbian Cyrillic)

Popović-Obradović, O. „Koreni antimoderne političke kulture u Srbiji“, u: L. Perović, Dominantna i neželjena elita: beleške o intelektualnoj i političkoj eliti u Srbiji (XX-XXI vek), Beograd/Novi Sad: Dan Graf/Radio-televizija Vojvodine, 2015.

Popper, K. Otkritoe obštestvo i ego vragi, 1, Moskva: Nauka, 1992. (Russian Cyrillic)

Protić, M. „Protić i Pašić pre 1914.“, Istorijski glasnik, 1, 1971. (Serbian Cyrillic)

. Radikali u Srbiji: ideje i pokret (1881-1903), Beograd: Balkanološki institut SANU, 1990.

(Serbian Cyrillic)

. „The Serbian Radical Movement 1881-1903: A Historical Aspect“, Balcanica, 36, 2005.

. „Sources of the Ideology of Serbian Radical Movement 1883-1903“, Balcanica, 37, 2006.

. „Najviša tačka učenosti među Srbima“, u: Pola veka od smrti Slobodana Jovanovića: povratak u nacionalnu baštinu i domovinu“", NIN: specijalni dodatak, 16. oktobar 2008. (Serbian Cyrillic)

Radenković, Đ. Pašić i Srbija. Beograd: Službeni list SRJ, 1997. (Serbian Cyrillic)

Ranee utro, 29 aprelja 1916.

Reč, 30. aprelja 1916. (Russian Cyrillic)

Rodionov, Iv. „Nikola Pašić u Petrogradu: povodom desetogodišnjice smrti“, Narodna odbrana, br. 1-2, 3. januar 1937. (Serbian Cyrillic)

Russkie vedomosti, 3. maja 1916. (Russian Cyrillic)

Sforca, K. Nikola Pašić i ujedinjenje Jugoslovena: ratne i diplomatske uspomene, Beograd: Kosmos/Geca Kon, 1937. (Serbian Cyrillic)

Skazkin, S. D. Konec avstro-russko-germanskogo sojuza, Moskva: Nauka, 1974. (Russian Cyrillic)

„Srpski radikalizam“, Odjek, br. 66, 7. maj 1889. (Serbian Cyrillic)

Spalajković, M. „Gospodin Pašić: državnik - diplomata - filozof, u: Spomenica Nikole P. Pašića (1845-1926), Beograd: Odbor za proslavu osamdesetogodišnjice Nikole P. Pašića, 1926.

Stanković, Đ. Nikola Pašić i jugoslovensko pitanje, 1, Beograd: Beogradski izdavačko-grafički 
zavod, 1985. (Serbian Cyrillic)

Šemjakin A. L. „Nikola Pašič i Rossija (1883-1889), u: Balkanskie issledovanija: Rossija i slavjane, Moskva: Institut slavjanovedenija RAN, 1992. (Russian Cyrillic)

. „Nikola Pašić u uspomenama ruskog putnika (prilog proučavanju idejnog porekla Srpske narodne radikalne stranke)“, Tokovi istorije, 3-4, 2003, 99-109.

. „Mitropolit Mihailo u emigraciji (Zajedno sa Nikolom Pašićem protiv Milana Obrenovića)“,

Zbornik Istorijskog muzeja Srbije, 31, 2003. (Serbian Cyrillic)

. (prir.). Mitropolit Mihailo i Nikola Pašić: emigrantska prepiska (1884-1888), Beograd:

Zavet, 2004. (Serbian Cyrillic)

- „Svet detinjstva u Srba u putnim beleškama P. A. Rovinskog“, u: Žene i deca. Srbija u modernizacijskim procesima XIX i XX veka 4, Beograd: Helsinški odbor za ljudska prava, 2006. . Ideologija Nikole Pašića: formiranje i evolucija (1868-1891), Beograd: Zavod za udžbenike i nastavna sredstva, 2008. (Serbian Cyrillic)

. „Narod i vlast v nezavisimoj Serbii“, Godišnjak za društvenu istoriju, 1-3, 2008, 7-31. (Russian Cyrillic)

. et al. Moskva - Serbija, Belgrad - Rossija: sbornik dokumentov i materialov, 3: Obštestvenno-političeskie $i$ kuljturnije svjazi, Moskva/Beograd: Glavnoe arhivnoe upravlenie/Arhiv Srbije, 2012. (Russian Cyrillic)

. „O istokov Narodnoj radikaljnoj partii: Nikola Pašič i Pera Todorovič - druzja-soperniki“, u: V. Matović i B. Zlatković, Pera Todorović - novi (p)ogledi: političke ideje i književnopublicističko delo, Beograd/Smederevska Palanka: Institut za književnost i umetnost/Biblioteka „Milutin Srećković“, 2014. (Russian Cyrillic)

- „Serbija i serbi nakanune Balkanskih vojn glazami russkih (k diskussii o „sovremennom“ gosudarstve)“, Tokovi istorije, 1, 2015. (Russian Cyrillic)

. „Čto za podlec i merzavec etot Milan: Aleksandr III i političeskaja elita nezavisimoj Serbii“, Rodina, 2 (specialjnjij vipusk), 2015. (Russian Cyrillic)

„Osobennosti političeskogo processa v nezavisimoj Serbii (1878-1918): meždu nacionaljnim idealom i graždanskim obštestvom“, u: Čelovek na Balkanah: osobennosti «novoj» južnoslavjanskoj gosudarstvennosti: Bolgarija, Serbija, Černogorija, Korolevstvo SHS v 1878-1921, Moskva: Institut slavjanovedenija RAN, 2016, 187-194. (Russian Cyrillic)

Šijački, D. „Nikola P. Pašić“, u: Pašić: ilustrovani radikalni almanah. Građa za pedesetogodišnju istoriju Narodne radikalne stranke i političku istoriju Srbije, 2, Beograd: bez izdavača, 1925. (Serbian Cyrillic)

Terzić, S. „Slovenofilstvo Nikole Pašića“, u: Nikola Pašić: život i delo, Beograd: Zavod za udžbenike i nastavna sredstva, 1997. (Serbian Cyrillic)

Trgovčević, Lj. „Srpska inteligencija u XIX veku - zapadni i istočni uticaji“, u: S. Terzić (ur.). Evropa i Srbi, Beograd/Novi Sad: Istorijski institut SANU/Pravoslavna reč, 1996. (Serbian Cyrillic)

Trifunović, M. „Nikola Pašić“", Srpski književni glasnik, 20, 1927. (Serbian Cyrillic)

Trockij, L. D. Pered istoričeskim rubežom: Balkani i Balkanskaja vojna, Sankt-Peterburg: Misl, 2011. (Russian Cyrillic)

Trubeckoj, G. N. „Russkaja diplomatija 1914-1917 gg. i vojna na Balkanah“, u A. L. Šemjakin (prir.). Russkie o Serbii i serbah, I (pisma, statii, memuari), Sankt-Peterburg: Aleteja, 2006. (Russian Cyrillic)

Višnjić, Č. „Srbobran“ 1901-1914, „Srpsko kolo“ 1903-1914, Beograd/Zagreb: Prosveta, 2013.

Vrkatić, L. Pojam i biće srpske nacije: Sremski Karlovci - Novi Sad: Izdavačka knjižarnica Zorana Stojanovića, 2004. (Serbian Cyrillic)

Žutić, N. Liberalizam i Srbi u prvoj polovini XX veka: iz historije ideologije građanskog liberalizma, Beograd: Institut za savremenu istoriju, 2007. (Serbian Cyrillic) 


\section{ANDREY L. SHEMYAKIN \\ Institute for Slavic Studies of the Russian Academy of Sciences \\ NIKOLA PAŠIĆ AND RUSSIA. FROM THE HISTORY OF MUTUAL RELATIONS}

\section{Summary}

The paper presents a review of various opinions regarding the nature of Nikola Pašić's Russophilism. Some historians and publicists believe that it was purely pragmatic, while others emphasize the Russian-Serbian Slavic and confessional unity as a decisive factor. The second part of the paper directly discusses the nature of Pašićs "unconditional" choice of Russophilism. According to the author, it stems from different understandings of the further lines of the development of Serbia after 1878. While King Milan Obrenović and the Advanced Party were pro-West oriented, Pašić and the Radical Party, like all Russian Slavophiles, were in favor of preserving Serbian identity. Finally, the author gives a short history of practical relationships of Nikola Pašić and Russian official circles and society.

Keywords: Nikola Pašić, Russia, ideology, Slavophilism, Westerners, modernisation of Serbia, Milan Obrenović, Alexander III, Nicholas II.

(C) Faculty of Philosophy, Novi Sad, 2016

ISTRAŽIVANJA - JOURNAL OF HISTORICAL RESEARCHES 27, 200-224 